\title{
The long goodbye: Age, demographics, and flexibility in retirement
}

\author{
David K. Foot \\ Professor Emeritus \\ Department of Economics \\ University of Toronto
}

\author{
Rosemary A. Venne \\ Department of Human Resources and Organizational Behaviour \\ Edwards School of Business \\ University of Saskatchewan, Saskatoon \\ E-mail:venne@edwards.usask.ca
}

\begin{abstract}
The current literature on retirement decisions has given inadequate attention to the impacts of increasing life expectancy. This paper examines workforce aging and retirement within a framework that not only includes age, but also integrates increasing life expectancy into the discussion. Employee preference surveys regarding choice in retirement are supported by the demographic and by work-time compression arguments for retirement flexibility. We outline arguments why partial-retirement policies would be a practical and timely transition strategy for organizations and societies in a world of increasing life expectancies and aging workforces, especially when facing the imminent retirement of the large post-war baby-boom generation.
\end{abstract}

Keywords: Workforce aging, life expectancy, partial retirement.

\section{Résumé}

La littérature actuelle sur les décisions relatives à la retraite n'accorde pas assez. d'importance à l'effet d'une plus grande espérance de vie. Cet article examine le vieillissement de la population active et la retraite dans un cadre qui ne comprend pas seulement l'âge, mais qui intègre aussi une plus grande espérance de vie au débat. Les sondages sur les préférences des employés en ce qui concerne les choix de retraite se basent sur les données démographiques et les arguments relatifs aux compressions de travail pour une plus grande souplesse à l'égard de la retraite. Nous donnons des arguments voulant que les politiques en faveur de retraite partielle soient une stratégie de transition pratique et opportune pour les organisations et les sociétés dans un monde de plus grande espérance de vie pour les populations actives vieillissantes, surtout face à la retraite imminente de l'importante génération du baby-boom de l'après-guerre.

Mots-clés : vieillissement de la population, espérance de vie, retraite partielle. 


\section{Introduction}

"Gloom and doom" articles dealing with population aging and, in particular, the aging of the labour force, abound in North America. Most of these articles focus on the impending retirement of the large post-war baby-boom generation. For example, a recent newspaper headline warned that "the transition [to an aging society] will be large and abrupt" (Milner and Scoffield 2009). In addition, retirement of the baby-boom generation is frequently fingered as the culprit for future labour force shortages (e.g., see Conference Board of Canada 2006). While there is no doubt that both the Canadian population and labour force are aging, the process is gradual (not abrupt), has been anticipated for many years, and can be handled with creative policies to ameliorate its impacts. This paper discusses these issues within a framework that not only includes age in the retirement decision, but also takes into account rising life expectancy.

We first outline the role of changing demographics over the post-war period, focusing on observed increases in life expectancy. In general, the large body of literature on retirement does not adjust for increases in life expectancy. We address this gap and note that these increases have been ongoing and substantial—approximately two years a decade - and that omitting this influence from theoretical models and policy discussions has been a critical oversight in the retirement literature.

We review the recent relevant literature on workforce aging and show how the observed trends and survey results are more richly interpreted within the context of this alternative framework. What is missing from much of the discussion is an integration of life expectancy into retirement issues. To begin with, we present an overview of historical trends in life expectancy and retirement. We then consider labour force participation rates and explore employee preference surveys for flexibility in retirement. Next, we review the growing literature on workforce ageism and related productivity concerns. We then outline work-time compression arguments for retirement flexibility. Finally, we present arguments why flexible or partial retirement would be a practical, timely, and useful transition strategy for organizations and society toward formally recognizing increases in life expectancy. We conclude with a discussion of some policy initiatives that would encourage flexibility in the baby-boom generation's retirement decisions.

\section{Life expectancy and retirement}

Almost all studies in aging use the concept of chronological age- number of years since birth—as the explanatory variable. Very few studies in aging have defined and used the expected number of years left to live as the explanatory variable. In a seminal paper in the health economics literature, Zweifel et al. (1999) contended that in explaining healthcare expenditures, the term "years lived"-namely, chronological age-was a "red herring," and that "years left to live" eliminated the significance and importance of chronological age as an explanatory variable. More recently, demographers Sanderson and Scherbov $(2007,2008)$ have argued that we should think of people as having two ages, the usual chronological age (number of birthdays experienced) and the number of remaining birthdays a person can expect, 
or one's remaining life expectancy. ${ }^{1}$ They point out that none of the common tools for discussing population aging adjust for increases in life expectancy.

To discuss remaining life expectancy with respect to Canadian data, we begin with an examination of life expectancy and retirement. Over the fifty-five-year period between 1951 and 2006, life expectancy in Canada increased from 68.6 years to 80.8 years - an increase of 12.2 years, or 18 per cent. For males the increase was 12.1 years, while for females the increase was 12.2 years. However, as dramatic as these numbers are, the results are even more dramatic when viewed from the perspective of expected number of years in retirement. A first indication of just how important these increases have been can be measured by calculating the expected number of years left to live after retirement at some fixed age, say 65 years. In 1951 the average Canadian worker could anticipate 3.6 years of retirement if she/ he remained in the workforce until age 65. By 2006, this number had risen to 15.8 years, more than a fourfold increase. For males the increase was from 1.3 to 13.4 years, while for females it was from 5.8 to 18 years. These are low estimates; an earlier retirement would increase these numbers, as would a calculation based on remaining life expectancy for individuals who have already reached age 65 .

These numbers can be used to integrate life expectancy into the retirement decision. In 1976, based on a retirement age of 65, the average person could expect to live an additional 9.2 years. With this arbitrary "standard," the equivalent retirement age in 1951 that promised 9.2 years in retirement would have been 59.4 years, and in 2006 it would have been 71.6 years. Alternatively, a relative rather than absolute standard could be used. The 9.2 years in 1976 represented 12.4 per cent of expected life expectancy in retirement. The equivalent proportion applied to life expectancy produces a life-expectancy-adjusted retirement age of 60.1 in 1951 and 70.8 in 2006.

Academic and policy work on population aging and retirement has sometimes acknowledged, but has not usually taken into account, these life-expectancy increases. For example, many pension plans have maintained age 65 as the basis for determining retirement benefits for members, and for the calculation of the actuarial value of their pension plans. These calculations have resulted in "pension holidays" in good economic times and "pension shortfalls" in bad economic times, with significant implications for the long-term viability of the sponsoring organizations and plans. In fact, the above increases in the expected number of years in retirement pose a significant challenge to many pension plans and help to explain why there has been a decided shift from defined benefit to defined contribution (or even the withdrawal of) pension plans in recent years.

Moreover, this discussion ignores trends in retirement ages. Table 1 incorporates recent trends in retirement, as well as information on actual life expectancy at age 65 . The first column shows life expectancy at birth. The second column shows

1. Sanderson and Scherbov's concept of 'prospective age' (2007, 2008), which they define as the number of remaining birthdays a person can expect, is a relatively new measure. Prospective age assigns age to people on the basis of their remaining life expectancy, so, for example, 65-year-olds in 1900 and 65-year-olds in 2000 would have very different prospective ages, due to rising longevity. They acknowledge that the concept of prospective age is rarely used in demography, but point out there is a deficiency, in that none of the common tools (e.g., the proportion of elderly in the population or median age) for discussing population aging adjust for increases in life expectancy. 
Table 1: Life expectancy and retirement: Canada, 1976-2006 (yrs.).

\begin{tabular}{|c|c|c|c|c|c|}
\hline Year & $\begin{array}{c}\text { Life } \\
\text { Expectancy } \\
\text { at Birth } \\
\text { (LE) }\end{array}$ & $\begin{array}{c}\text { Life } \\
\text { Expectancy } \\
\text { at Age } 65 \\
\left(\mathrm{LE}_{65}\right) \\
\end{array}$ & $\begin{array}{c}\text { Average } \\
\text { Age of } \\
\text { Retirement } \\
\text { (AAR) }\end{array}$ & $\mathrm{LE}-\mathrm{AAR}$ & $\mathrm{LE}_{65}-\mathrm{AAR}$ \\
\hline \multicolumn{6}{|l|}{ TOTAL } \\
\hline 1976 & 74.2 & 81.3 & 64.9 & 9.3 & 16.4 \\
\hline 1981 & 75.3 & 82.0 & 64.6 & 10.7 & 17.4 \\
\hline 1986 & 76.6 & 82.2 & 63.7 & 12.9 & 18.5 \\
\hline 1991 & 77.8 & 83.0 & 62.7 & 15.1 & 20.3 \\
\hline 1996 & 78.4 & 83.2 & 61.8 & 16.6 & 21.4 \\
\hline 2001 & 79.6 & 84.0 & 61.5 & 18.1 & 22.5 \\
\hline 2006 & 80.8 & 84.9 & 61.5 & 19.3 & 23.4 \\
\hline \multicolumn{6}{|c|}{ FEMALES } \\
\hline 1976 & 77.8 & 83.3 & 63.9 & 13.9 & 19.4 \\
\hline 1981 & 78.6 & 84.2 & 63.5 & 15.1 & 20.7 \\
\hline 1986 & 79.9 & 84.3 & 62.8 & 17.1 & 21.5 \\
\hline 1991 & 80.9 & 84.9 & 62.1 & 18.8 & 22.8 \\
\hline 1996 & 81.2 & 84.9 & 60.9 & 20.3 & 24.0 \\
\hline 2001 & 82.1 & 85.6 & 60.3 & 21.8 & 25.3 \\
\hline 2006 & 83.0 & 86.4 & 60.7 & 22.3 & 25.7 \\
\hline \multicolumn{6}{|l|}{ MALES } \\
\hline 1976 & 70.5 & 79.2 & 65.3 & 5.2 & 13.9 \\
\hline 1981 & 72.0 & 79.7 & 65.1 & 6.9 & 14.6 \\
\hline 1986 & 73.3 & 80.0 & 64.1 & 9.2 & 15.9 \\
\hline 1991 & 74.6 & 80.8 & 63.1 & 11.5 & 17.7 \\
\hline 1996 & 75.4 & 81.1 & 62.3 & 13.1 & 18.8 \\
\hline 2001 & 77.0 & 82.0 & 62.3 & 14.7 & 19.7 \\
\hline 2006 & 78.4 & 83.2 & 62.1 & 16.3 & 21.1 \\
\hline
\end{tabular}

Source: Columns 1, 2: Statistics Canada (2009a, 2009b); column 3: Statistics Canada (2009c); Columns 4, 5 calculations by the authors.

life expectancy at age 65. The numbers in the second column are higher than those in the first column because they are based only on persons who have survived to age 65 . The third column presents the actual average age of retirement. ${ }^{2}$ The final two columns calculate the number of years in retirement, first using life expectancy at birth and then using life expectancy at age 65. The final two columns reveal the increasing number of years that people are spending in retirement, with increases in life expectancy and decreases in the average age of retirement.

The results (last column) indicate that over the thirty-year period from 1976 to 2006 the average number of years in retirement increased from 16.4 to 23.4 years, an increase of 7 years, or 42.7 per cent. For males the increase was from 13.9 to 21.1 years, an increase of 7.2 years (52 per cent), while for females it was from 19.4 to 25.7 years, an increase of 6.3 years (32 per cent). By 2006, the average Canadian male could anticipate over 21 years of retirement, and the average

2. The Labour Force Survey asks people who are not working, and who have left their last job within the year prior to being surveyed, why they left this job. One of the response categories is "retired." The average or median retirement age is calculated from this variable (Statistics Canada 2008). 
Canadian female could expect over 25 years of retirement. Since life expectancy at the (variable) actual retirement age is slightly lower than at age 65, these estimates should be considered as upper estimates. Nonetheless, these are substantial increases in a relatively short time period.

These calculations give some indication of how remaining years of life can be integrated with retirement decisions, planning, and policies. The increases in expected years in retirement reflect both increases in life expectancy and reductions in the average age of retirement over the period. The former is likely to continue, but the latter may or may not (see below). These calculations also lead us to examine a number of issues that will be considered in the remainder of this paper, beginning with labour force aging and followed by retirement preferences, ageism, work-time compression, and, finally, policy considerations.

\section{Labour force aging and participation}

Several recent labour force projections have pointed out the inevitable aging of the labour force. In the Martel et al. (2007) projections, the aging of the labour force would be slightly more pronounced, assuming a continued increase in the participation rate of older workers. However, they also point out that a continued increase in participation rates for older workers has the potential to delay by only a few years the inevitable decline in the "overall" participation rate. A Policy Research Initiative report (PRI 2005) notes that the labour force will begin to decrease during the 2010s, not in absolute numbers but as a proportion of the overall population.

Labour force participation rates have increased among Canadians aged 55plus in recent years, which seems to be a reversal of the steady decline in the retirement age since the mid-1970s (see Table 1). The determinants of labour force participation are many and varied, but Marshall and Ferrao (2007) point out that overall participation rates are expected to increase with rising educational attainment. Rising levels of education, improved health, less physically demanding jobs, and a greater share of workers in professional occupations, which are all associated with higher participation rates, are likely to encourage people to remain in the labour force longer (Judy and D’Amico 1997; Rix 2008). Since current women's labour force or career attachment is much stronger throughout the life cycle compared to past generations, as new generations of women reach their retirement years, higher participation rates are expected (Marshall and Ferrao 2007). All of these reasons point to rising participation rates, especially among older workers.

Recent survey data indicate that worker preferences are for flexibility in labour force participation and in the retirement decision. There is little dispute that older workers often desire transitional or partial retirement. In their article on retaining older workers, Morissette et al. (2004) report from the Canadian General Social Survey of 2002 that over one-quarter of retired respondents indicated that they likely would have changed their decision to retire if they had been able to reduce their work schedule without their pension being affected, by working either fewer days per week or shorter days. University-educated retirees were most likely to have continued working. They also point out that a worsening financial situation will unambiguously affect one's view of continuing to work. 
Schellenberg and Ostrovsky (2008) note the strong prevalence of uncertainty in terms of older workers' retirement expectations, and that such uncertainty is more widespread in Statistics Canada's 2007 General Social Survey compared to previous surveys. There is evidence that Canadians in their late 40s and early 50s have delayed their planned age of retirement. Also, a recent large-scale survey of Americans after the economic downturn of 2008 revealed that many plan to reset their retirement clock, as respondents on average plan to postpone retirement by 4.2 years (Age Wave 2009). American opinion polls consistently indicate that twothirds or more of middle-aged and older workers plan to work in some capacity in retirement (Rix 2008). One US study suggests that increased flexibility in work schedules (if provided by employers) would actually double the number of people entering partial retirement (Munnell and Sass 2008).

In terms of work-time flexibility, Gendron (1997) notes that surveys of older workers indicate that the majority want gradual or transitional retirement. In the province of Quebec, this survey documents public support for the concept of gradual or transitional retirement, with greatest interest in those at mid-age and nearing retirement. Preference for working 3.5 days per week at age 55, with a gradual reduction in hours until they are working 0.5 days per week at age 70 , was at 75 per cent for those aged 45-54 and 72 per cent for those aged 25-44 (Gendron 1997). If employers were to provide these work-time flexibilities, it is likely that older employees would be encouraged to work at later ages.

A more recent survey of Canadian workers remarks that the ideal work week for older workers is Tuesday to Thursday from nine to noon. Though the majority of workers indicated a desire to take full retirement when eligible, a significant minority indicated either a preference for gradual phased-in retirement or to retire and then work on a gradual basis (RBC 2008). Close to half of older workers (55+ years) who were dissatisfied with their work-life balance report spending too much time on the job (Uriarte-Landa and Hebert 2009). This is different from core-age workers, who are most likely to associate work-life balance dissatisfaction with "not enough time for family."

Marshall and Ferrao (2007) suggest that older workers are making a conscious transition towards retirement, with two-thirds of older part-time workers having a shorter work week by preference.

\section{Productivity concerns and age discrimination}

The possibility of increasing numbers of aging workers in the labour force raises issues of productivity and age discrimination that are often related to older workers. For example, Martel et al. (2007) note that an increased number of older workers could affect labour productivity in the future, while pointing out that future economic growth will have to rely less on population (growth) and more on higher productivity. While different authors draw on different data sources, common themes emerge from their research findings. In a preliminary study of full-time male workers (using several decades of US census and population survey data), Laitner and Stolyarov (2005) directly ask whether labour productivity is age

dependent. They tentatively conclude that aging of the labour force should boost an economy's average productivity per worker, since the fact of population aging 
raises the proportion of workers with an accumulation of human capital from experience. Disney (1996) also concludes that there is no evidence of adverse effects of aging on aggregate productivity. There is simply no evidence of a negative association between the average age of the workforce and labour productivity. England (2002) tackles the subject of forecasting the economic effects of aging. He points out the difficulty of forecasting in that "one must consider how people will behave in situations that have no historic precedent" (2002: 2).

Segrave (2001) discusses a variety of workplace research which shows that older workers are at least equal to their younger counterparts in productivity, with slight decreases noted where there was substantial physical effort required. Munnell and Sass (2008) view any productivity gap between older and younger workers as minimal. While cognitive flexibility and ability to learn do decline slightly, they feel that older workers have sufficient mental agility to learn and adapt, if given training. Beatty and Visser (2005) also challenge the myth of older workers and their inability to learn. In particular, they point out that any differences in learning between older and younger workers are accounted for by improving training design and delivery. Making training age-friendly does not mean making it youth-unfriendly.

One potential problem is that employers may resist training older workers, as they fear a shorter payback period to recoup their training investment. Robson (2001) notes that a legitimate question for employers is whether spending incremental training resources on older workers is a good investment, as the total time over which to amortize their training costs might be less than that of a younger worker. Yet he points out that older workers' shorter expected time in the workforce may not translate into shorter expected tenure with a given employer. In fact, a number of researchers point out that job turnover is lower among older workers than younger workers (Robson 2001). Rothwell et al. (2008) also note that older workers have lower turnover rates, absenteeism, and injury rates.

Despite the above findings, Hedge et al. (2006) call age discrimination the most socially accepted form of prejudice, very ingrained in our society despite the fact that there is a lack of clarity as to the definition of who exactly is an "older worker." Burchett (2005) notes that of the three forms of discrimination-racism, sexism, and ageism-not everyone will experience the first two, yet anyone who lives long enough may be a victim of age discrimination. Whereas race and gender discrimination are usually regarded as irrational, he points out that some view age discrimination as a sound business practice. Hedge et al. (2006) note the pervasive nature of age discrimination in employment, and the persistence of negative stereotypes of older workers, especially in the area of training. They discuss the stereotypes as self-fulfilling prophecies, and recommend that human resource specialists need to gain a better understanding of issues surrounding older workers. They remark that age discrimination complaints are on the rise in the US, though with the caveat that with an aging labour force there are simply more eligible people subject to discrimination. In Canada, age discrimination complaints have also been rising recently, according to the Canadian Human Rights Commission (CHRC 2010).

There seems to be agreement in human resource circles that ageism abounds in the workplace. Rix posits that "it is hard to imagine that age will ever not be a factor in employers' personnel decisions" (2008: 132). Despite the fact that job 
tenure has declined (see Cappelli 2008) and the fact that most workers do not have a lifetime career at a single workplace, employers often have an implicit, or sometimes explicit, preference for a younger employee over an older employee. Often the stated reason for the preference is that the younger person will remain longer on the job. The main factor influencing the shedding of senior workers is the cost calculation, done without regard to the value of experience or other factors (such as loyalty and lower absenteeism; see Venneberg and Eversole 2010). It is possible that actual knowledge of older workers' lower absenteeism or discussion of labour force shortages may help employers to value older workers more highly. Discussion of lower job turnover and workplaces' positive experiences in hiring older workers (such as the targeted hiring of older workers at Home Depot hardware stores) may help (see Rix 2008). The Canadian Association of Retired People (CARP) and American Association of Retired People (AARP) give recognition to employers based on their positive treatment of older workers. Combating age discrimination can be done with information and ad campaigns aimed at educating and challenging employers' stereotypes about older workers.

Segrave (2001) traces the history of age discrimination in the US, and points out that legislation has removed the obvious trappings of age bias (such as helpwanted ads specifying an age range), but in practice the law has helped only within a very narrow range, and that age bias still persists. There are, obviously, limits to legislative protection. Munnell and Sass (2008) caution that strengthening age discrimination legislation may not be a viable solution, as age discrimination is hard to prove or disprove. For example, Barry Witkin, who founded Prime 50, an employment service for aged-50-plus workers in Canada, notes that a fair amount of age discrimination exists but that it is couched in terms "such as a person won't fit in or that they are overqualified or that they may be too expensive" (Galt 2006). Also, any strengthening of legislation may have the unintended effect of employers reacting to a tougher legal environment by avoiding older workers altogether.

The Urban Institute's Retirement project (2007) asks: "Are employers willing to hire and retain older workers?" While it notes that employer attitudes toward older workers are mixed, the expectation is that future demand for older workers may increase, due to demographics and job demand. For example, the expectation is that jobs in the future will be more cognitively challenging and less physically demanding, and require more interpersonal skills, which benefits older workers. Erickson (2008) optimistically predicts that the shift to knowledge-based positions and fewer physically demanding jobs will result in a workplace less marked by concerns about ageism.

An example of the positive demand for older workers in partial retirement has been presented by DeLong (2004). He predicts that many organizations will be overwhelmed with threats of lost knowledge due largely to baby-boomer retirements. In the past few decades, the industrialized world has experienced unprecedented advances in technology and scientific domains, made possible in large part by the proliferation of information technologies. DeLong recommends developing a human resource infrastructure for knowledge retention, including partial retirement and methods of knowledge transfer. Despite strong interest in these partial-retirement programs, they tend to be offered informally and are limited in scope, due to a range of legal barriers that make it difficult to implement these 
programs. He expects that there will be pressure to ease the restrictions against and formalize these programs. He acknowledges that partial retirement is just a stop-gap measure unless it includes measures such as training and mentoring to transfer knowledge. The periods of partial retirement can allow organizations to use employees' expertise in roles such as mentors, trainers, and consultants, and in special assignments. In terms of partial retirement, Erickson (2008) discusses cyclical or project-based work, defined as hard work interspersed with leisure, as one popular option. Another flexible option is for a retiree-on-call program, where employees are hired back on a contract basis (Galt 2006). Munnell and Sass (2008) also echo these concerns about lost institutional knowledge, with the caveat that these concerns may be industry-specific rather than widespread.

\section{Demographics and work-time compression}

Having discussed various concerns regarding labour force and aging, it is time to discuss two additional trends that support the case for timely action on these issues. These are the demographic and work-time compression arguments for contributing to increasing older worker participation in the labour force. The impending retirement of the large baby-boom generation in North America intensifies the need for addressing these issues. Many baby-boomers born in the late 1940s have started to retire, and the much larger group born in the 1950 s are poised to enter their sixties over the decade 2010-2020. With ever more people entering the older worker category (however it is defined), the demographic impetus for developing and implementing flexible or partial-retirement policies is becoming increasingly important. Worker preference for these options has been outlined above, and the higher average educational levels of this generation, and increased numbers, are likely to impose greater pressures on employers and governments for solutions.

Moreover, the trends outlined above (see Table 1) indicate that there has been a noticeable compression in the portion of the average worker's life devoted to labour force participation. Sunter and Morisette (1994) note that the trends to more education and earlier retirement, coupled with longer life expectancy, have shortened or compressed the portion of the life cycle devoted to paid work, and quite noticeably so, in the last quarter of the 20th century. For example, by the late 20th century, workers (e.g., males at age 16) will spend 69 per cent of their remaining life expectancy in the labour force, compared to 90 per cent for workers (again, males at age 16) earlier in the 20th century.

Will the baby-boomer generation be working longer? While it is impossible to model employer demand, recent research suggests that workers will consider working longer at jobs they enjoy, assuming good health and flexible working conditions (Ibbott et al. 2006). With the distinction between middle age and old age being blurred, and with many of those aged 65-plus belonging to the "young-old" group of active seniors, Thorpe (2002) contends that it is time to question who we consider to be "old." Rix (2008) describes old age as being pushed back, with general increases in health status at older ages. Ibbott et al. (2006) point out that with disability-free life expectancy on the rise, Canadians experience a longer period of labour force inactivity in relatively good health. 
Given industrialized countries' concerns regarding the aging population and future labour force supply, some researchers have pointed out that our retirement age is early, relative to our rising life expectancy. This fact has been noted especially in Japan, a country whose people have some of the world's longest life expectancies. Myles (2005) advises that we need to take advantage of our increased longevity gains by offsetting our longer period of transition into adulthood with later retirement ages (see Beaujot and Kerr 2007 regarding delayed transitions). Given our increased life expectancy, Munnell and Sass (2008) point out that working longer does not mean having fewer years in retirement than workers earlier in the postwar era. This point is consistent with our calculations in Table 1. Indeed from Table 1, we see that even working three years longer, a person would still have four more years of retirement in 2006 compared to 1976.

Sanderson and Scherbov (2008) point out that a 60-year-old man in Western Europe today has about the same remaining life expectancy as a 43-year-old man in 1800. They lament that none of our common tools for discussing population aging adjust for these increases in life expectancy. With these increases in life expectancy, they question our commonly used indicators of aging that assume that people become old at the chronological age of 65. Erickson (2008: 61) speaks of the longer life expectancy not in terms of prolonging our years of being old but of potentially extending our period of an active middle age (which has been compressed of late). She proposes that we deal with the looming baby-boomer retirement by tapping into our longer life expectancy in order to "retire retirement."

\section{Policy initiatives}

Taylor (2002) describes policymaking on age and employment as being in its infancy. McMullin et al. (2008) lament that only a few policy changes concerning retirement have been made, and that these are more likely to be driven by concerns about the economic consequences of population aging than by concerns for the well-being of older workers (see, for example, Government of Canada 2006). They also note that there is little evidence of a coherent policy framework for addressing the challenges of population aging. A Policy Research Initiative report (PRI 2005) describes a current employment system that is still tilted towards early retirement. Indeed, for the past two decades organizations have used early retirement plans and buyouts to make room for younger workers (Galt 2006). Policies to encourage later retirement are seldom discussed, let alone implemented.

Markham and Timmins (2001) suggest that a practical partial retirement program would allow an employee to work part-time and accrue benefits based on hours worked while at the same time collecting a pension for days not worked. Brown et al. (2001) outline how this flexibility might be manifested for the individual worker. For example, they propose that a worker might work Tuesday through Thursday and contribute to a pension plan, and then take Monday and Friday off and draw pension benefits on those two days. Alternatively, they propose another example whereby an individual's work year would consist of work for seven months of the year, during which the worker would be employed fulltime and contribute to a pension. For the other five months, the worker would be considered retired and draw from the pension plan. 
Compared to North America, European countries seem to be more willing to experiment and encourage creative retirement programs. For example, a comparative study of transitional-retirement programs found that a majority of European Union countries have introduced legislation allowing transitional or partial retirement (Pedersini 2001). These European schemes aim at retaining older people within the active population by decreasing their working time and at the same time granting some sort of income-support measure. A typical example is a program that allows an older worker to work half-time from the age of 55 until full retirement age, with pay for time worked and a pension for the remainder of the time. In contrast, a BNAC survey mentions that most American employers who did not have phased-retirement programs cited as a reason for not offering them the simple fact that they had never considered them (Robson 2001).

Bass (2005) refers to older workers as the only untapped pool of highly skilled labour that can be called upon during possible labour shortages. ${ }^{3} \mathrm{He}$ proposes career services, such as elder-opportunity organizations, for older workers wanting to return to work. Japan for example, has established a number of organizational structures to assist older workers with jobs after traditional retirement. North America has CARP and AARP (Canada and US, respectively), which function as advocacy groups for older workers. Munnell and Sass (2008) also propose government counselling, re-training, and job matching services for older workers.

The same constraints or reservations that employers have against job sharing, part-time work, and reduced work-weeks will also be issues with transitional or partial retirement. For example, employers may have difficulty shifting full-time job duties into the part-time realm. Munnell and Sass (2008) point out that parttime employment is expensive in the sense that the employer must spread out the cost of recruiting, training, scheduling, and evaluating workers over fewer hours of labour. It is certainly not impossible, as many employers have discovered savings and flexibilities in using these schedules. For example Olmsted and Smith (1997) discuss savings in terms of retention of valuable skills and expansion of the recruitment pool. White (1987), for example, points out that evidence shows that there are gains in work performance as hours are shortened, and losses as hours become long. Thus, one obstacle to partial retirement is the nature of the fixed costs per employee. Various solutions deal with lowering the cost of hiring older workers. One proposed solution is a cap on Employment Insurance (EI) for older workers past retirement age, such that older workers no longer pay into (or receive) EI. Munnell and Sass (2008) suggest eliminating payroll taxes for employees aged 62 plus in the US.

On the other hand, several researchers make the case for non-age-specific policies for older workers. For example, Taylor (2002: 38) states that programs developed for older workers are simplistic, in that chronological age is of limited value in determining employment-related needs of any person, "as if this [age] is always an older person's most important characteristic.” In this matter, Rix (2008) seems to concur, in that properly designed policies that aim to expand employment opportunities for older people should benefit workers of all ages. They point

3. Many countries are still dealing with the after effects of the most recent recession. It is hard to predict whether or not there will be shortages over this coming decade. Of course there are always shortages in some specific work areas. See Cappelli (2003) on this issue. 
out that there is a danger in tailoring policies only for older workers. Nevertheless, at the very least many policy analysts recommend information campaigns encouraging employers to consider older employees. Thus, positive marketing of older workers is proposed, resembling the "Freedom 55" insurance advertisements that portray younger seniors engaged in active leisure activities.

An International Labour Organization (ILO) publication (Auer and Fortuny 2000) recommends partial retirement, and describes a flexible work-retirement transition as a good example of active aging that has many advantages, including the retention of experience with the employing firm. Like Osberg (2005), Auer and Fortuny (2000) challenge the "boxes model of life," with its structured sequencing of education, paid work, and retirement. Osberg (2005) also notes that the baby-boom cohort has experienced more career instability than the smaller cohort that precedes it. Instead of policies directed only at older workers, support for workers in managing career risks throughout their working lives may be of more help. Life-long-learning policies such as tax incentives for education and work-life leaves for upgrading or changing careers, would be useful for all workers, especially with the increasing fragmentation in career patterns (see Thomas and Venne 2002).

The tide may be changing in Canada. Mandatory retirement has recently been banned in all jurisdictions in Canada, ${ }^{4}$ though several researchers expect that its abolition will not likely have a major impact on the age of retirement (Taylor 2002; Ibbott et al. 2006). The Canadian Expert Panel on Older Workers' report (HRSDC 2008) discussed barriers to increased labour force participation of older (55-plus) workers. The panel made several recommendations, including an awareness campaign to reduce ageism, elimination of mandatory retirement, and implementation of changes to tax and pension systems to remove barriers and disincentives to work. The federal government made some changes to the taxation act that allow employers to pay a partial pension to an employee while that same worker is also contributing to the pension plan. This will allow retirees to return to the workforce part-time (Tuck 2007). These tax policies, which recognize that individuals may be in receipt of both pension and employment income simultaneously, will be increasingly relevant. New rules for the Canada Pension Plan, to be phased in over 2011 to 2016, eliminate the cessation test that required a beneficiary to stop working, and encourage participants to work longer by increasing the penalty for early retirement (through a staged reduction of benefits from 0.5 to 0.6 per cent a month before age 65) and increasing the reward for delayed retirement (through a staged increase in benefits from 0.5 to 0.7 per cent per month up to age 70 ).

Pressures for a new strategy for retirement and pensions for all sectors may emerge from these initiatives - one that no longer requires a predetermined fixed retirement age for receipt of benefits or actuarial calculations, along with opportunities for workers to efficiently self-index their pensions according to individual needs.

4. Mandatory retirement has been banned in recent years in the following provinces: British Columbia (2008), Saskatchewan (2007), Ontario (2006), Nova Scotia (2009), and Newfoundland and Labrador (2007). All three of the territories, as well as Alberta, Manitoba, Quebec, Prince Edward Island, and New Brunswick, do not have mandatory retirement, though in New Brunswick companies are allowed to enforce it under "the terms or conditions of any retirement or pension plan" (CBC 2009). 
As a final point, the terms "flexibility" and "diversity" come up in most policy discussions. These terms are in recognition that the baby-boom group is not monolithic. On this point, McDaniel (2002) contends that the coming generations of seniors in Canada are quite different from previous generations in terms of ethnic diversity and family/gender-role changes experienced in the latter part of the twentieth century, in effect making the behaviour of the future elderly less predictable compared to past cohorts' behaviours. The Canadian Expert Panel on Older Workers' report (HRSDC 2008) also makes note of the considerable diversity in today's older workers' situations. Any new policy initiatives will need to be cognizant of these new realities.

\section{Conclusions}

Bass (2005) notes that the concept of retirement has shifted from an aspiration among older generations to being perceived as a universal expectation and right among current generations. In this paper, we propose that increasing life expectancy be integrated into the literature and policies concerning the retirement decision. Integration could include various flexibilities, such as partial-retirement schemes that remove barriers to work in terms of pension and taxation systems. We have documented that as a result of increases in life expectancy, there have been large increases in retirement years and a compression of working life for the average worker. We note that survey results indicate a strong demand for choice and flexibility in retirement and a strong interest in transitional or partial retirement, particularly among older workers. Under these conditions, encouraging partial retirement as a practical transition strategy for extending working lives makes sense, especially with the large, well educated baby-boom generation now poised to enter their retirement years. This policy would have the additional benefits of potentially ameliorating any future labour market shortage and generating additional taxes to support an aging population. Given that the earliest baby-boomer, born in 1947, reached the average retirement age of 64 in 2011, now is the time to implement these policies if Canada is to aim for a smooth workforce transition over the next two decades of baby-boomer retirement.

Rix (2008) contends that older workers clearly seem prepared to work longer, but would like to do it on their own terms. She speculates that the large babyboom generation will challenge the institution of retirement as they have shaped other institutions throughout their lives. How much the baby-boom generation will transform retirement is open to debate, but there will undoubtedly be pressures to alter the retirement environment to suit the diverse demands of this large generation. Given the documented desires for flexibility in retirement and increasing life expectancy, there needs to be, at the very least, removal of policies that discourage partial retirement (e.g., pension penalties) and promotion of policies designed to encourage an extension of the active middle years to take advantage of expanded life expectancy. These policies need to be flexible in order to capture the diversity of older workers, some of whom may have limiting health problems or may be involved in family care. The acknowledgment of increasing life expectancy provides a framework for retirement (and pension) policy design and change for the future. 


\section{References}

Age Wave. 2009. Retirement at the tipping point: The year that changed everything. www. agewave.com.

Auer, P., and M. Fortuny. 2000. Ageing of the labour force in OECD countries: Economic and social consequences. www.ilo.org.

Bass, S. 2005. New models for post-retirement employment, in Thriving on an Aging Workforce: Strategies for Organizational and Systemic Change, edited by P. Beatty and R. Visser. Malabar, FL: Krieger, pp. 161-9.

Beatty, P., and R. Visser (eds.). 2005. Thriving on an Aging Workforce: Strategies for Organizational and Systemic Change. Malabar, FL: Krieger.

Beaujot, R., and D. Kerr. 2007. Emerging Youth Transition Patterns in Canada: Opportunities and Risks. Policy Research Initiatives Project Discussion Paper. Ottawa: Government of Canada. www.policyresearch.gc.ca/doclib/DP_YOUTH_ Beaujot_200712_e.pdf.

Brown, R., R. Damm, and I. Sharara. 2001. A macro-economic indicator of age at retirement. North American Actuarial Journal 5(2):1-10.

Burchett, B. 2005. Employment discrimination, in Encyclopedia of Aging, edited by E. Palmore, L. Branch, and D. Harris. New York: The Haworth Reference Press, pp. $122-5$.

CHRC. 2010. Canadian Human Rights Commission Annual Reports. www.chrc-ccdp.ca.

Cappelli, P. 2003. Will there really be a labour force shortage? Organizational Dynamics 32(3):221-33. - 2008. Talent on Demand: Managing Talent in an Age of Uncertainty. Boston: Harvard Business Press.

CBC (Canadian Broadcasting Corporation). 2009. Mandatory retirement fades in Canada. www.cbc.ca/canada/story/2009/08/20/mandatory-retirement-explainer523.html.

Conference Board of Canada. 2006. Too few people, too little time: The employer challenge of an aging workforce. Executive Action Report, July. www. conferenceboard.ca/documents.aspx?DID $=1732$.

DeLong, D. 2004. Lost Knowledge: Confronting the Threat of an Aging Workforce. Oxford (UK): Oxford University Press.

Disney, R. 1996. Can we Afford to Grow Older: A Perspective on the Economics of Aging. Cambridge, MA: MIT Press.

England, R.S. 2002. The Macroeconomic Impact of Global Aging: A New Era of Economic Frailty? Washington, DC: CSIS Press.

Erickson, T. 2008. Retire Retirement: Career Strategies for the Boomer Generation. Boston: Harvard Business Press.

Galt, V. 2006. Thinking of working past 65? Think again. Globe and Mail, August 5, B12.

Gendron, L. 1997. Bye bye Boulot. L'Actualité, Juillet, 14-24.

Government of Canada. 2006. The demographic time bomb: Mitigating the effects of demographic change in Canada. Report of the Standing Senate Committee on Banking, Trade and Commerce. www.parl.gc.ca/39/1/parlbus/commbus/senate/ com-e/bank-e/rep-e/rep03jun06-e.pdf.

Hedge, J., W. Borman, and S. Lammlein. 2006. The Aging Workforce: Realities, Myths, and Implications for Organizations. Washington: American Psychological Association.

HRSDC (Human Resource Skills Development Canada). 2008. Expert panel on older workers. www.hrsdc.gc.ca/en/publications.

Ibbott, P., D. Kerr, and R. Beaujot. 2006. Probing the future of mandatory retirement. Canadian Journal on Aging 25(2):161-78.

Judy, R. and C. D'Amico. 1997. Workforce 2020: Work and Workers in the 21st Century. Indianapolis, IN: Hudson Institute. 
Laitner, J., and D. Stolyarov. 2005. Technological progress and worker productivity at different ages. University of Michigan Retirement Research Center working paper 2005-107, Ann Arbor, MI. www.mrrc.isr.umich.edu.

Markham, I., and P. Timmins. 2001. Phased retirement. Benefits Canada 25(9):51-4.

Marshall, K., and V. Ferrao. 2007. Participation of older workers. Perspectives on Labour and Income 8(8):5-11.

Martel L., E. Caron-Malenfant, S. Vezina, and A. Belanger. 2007. Labour force projections for Canada, 2006-2031. Canadian Economic Observer, June, www.statcan.ca.

McDaniel, S. 2002. Intergenerational linkages: Public, family and work, in Aging and Demographic Change in Canadian Context, edited by D. Cheal. Toronto: University of Toronto Press, pp. 22-71.

McMullin, J., M. Cooke, and T. Tomchick, 2008. Work and retirement in Canada, in Ageing Labour Force: Promises and Prospects, edited by P. Taylor. Cheltenham (UK): Edward Elgar, pp. 62-83.

Milner, B., and H. Scoffield. 2009. Aging: The growing cost, The Globe and Mail, July 9, B1-B4.

Morissette, R., G. Schellenberg, and C. Silver. 2004. Retaining older workers. Perspectives on Labour and Income 5(10):15-20.

Munnell, A., and S. Sass. 2008. Working Longer: The Solution to the Retirement Income Challenge. Washington, DC: Brookings Institution Press.

Myles, J. 2005. Postponed adulthood: Dealing with the new economic inequality. Canadian Council on Social Development. www.ccsd.ca/pubs/2005/pa/pa.pdf.

Olmsted, B., and S. Smith. 1994. Creating a Flexible Workplace. New York: AMACOM.

Osberg, L. 2005. Work and well-being in an aging society. Canadian Public Policy 31(4):41320.

Pedersini, R. 2001. Progressive retirement in Europe. European Industrial Relations Observatory. http://www.eurofound.europa.eu/eiro/.

PRI (Policy Research Initiative). 2005. Encouraging choice in work and retirement. Project Report. October. Ottawa: PRI.

RBC (Royal Bank of Canada). 2008. Special Report: Tuesday to Thursday, nine to noon: Ideal work week for older workers according to workplace survey. www.rbc.com/ newsroom/20080415survey.html.

Rix, S. 2008. Age and work in the United States of America, in Ageing Labour Force: Promises and Prospects, edited by P. Taylor. Cheltenham (UK): Edward Elgar, pp. 111-33.

Robson, W. 2001. Aging Populations and the Workforce: Challenge for Employers. BNAC (British North American Committee), Toronto: C.D. Howe Institute.

Rothwell, W., H. Sterns, D. Spokus, and J. Reaser. 2008. Working Longer: New Strategies for Managing, Training and Retaining Older Workers. New York: AMACOM.

Sanderson, W., and S. Scherbov. 2007. A new perspective on population aging. Demographic Research 16(2):27-58.

- 2008. Rethinking age and aging. Population Bulletin 63(4):3-16.

Schellenberg, G., and Y. Ostrovsky. 2008. The retirement plans and expectations of older workers. Canadian Social Trends (September):11-34.

Segrave, K. 2001. Age Discrimination by Employers. London: McFarland and Company.

Statistics Canada. 2008. Guide to the labour force survey: Definitions. http:/ /www. statcan.gc.ca/pub/71-543-g/2008001/5204157-eng.htm.

- 2009a. Historical statistics of Canada, Section B: Vital Statistics and Health, Series B65-74. Catalogue 11-516-XWE. http://www.statcan.gc.ca/bsolc/olc-cel/olccel?catno $=11-516-X \& l a n g=$ eng.

2009b. Life expectancy, abridged life table, at birth and at age 65, by sex, Canada, annually (Years), Table 102-0511. www.statcan.gc.ca. 
2009c. Labour Force Survey: Retirement age by class of worker and sex, annually (Years) Table 282-0051. www.statcan.gc.ca.

Sunter, D., and R. Morissette. 1994. The hours people work. Perspectives on Labour and Income 6(3):8-12.

Taylor, P. 2002. New Policies for Older Workers. Bristol (UK): Policy Press.

Thomas, M., and R.A. Venne. 2002. Work and leisure: A question of balance, in Aging and Demographic Change in Canadian Context, edited by D. Cheal. Toronto: University of Toronto Press, pp. 190-222.

Thorpe, D. 2002. Aging, language, and culture, in Aging and Demographic Change in Canadian Context, edited by D. Cheal. Toronto: University of Toronto Press, pp. 72-104.

Tuck, S. 2007. Workers allowed to semi-retire and still contribute to pension. Globe and Mail, March 20, A13.

Urban Institute. 2007. Fact sheets on retirement: The retirement project. www.urban.org/ retirement.

Uriarte-Landa, J., and B. Hebert. 2009. Work-life balance of older workers. Perspectives on Labour and Income 10(10):17-28.

Venneberg, D., and B. Eversole. 2010. The Boomer Retirement Time Bomb: How Companies can avoid the Fallout from the Coming Skills Shortage. New York: Praeger Publishers.

White, M. 1987. Working Hours: Assessing Potential for Reduction. Geneva: International Labour Organization.

Zweifel, P., S. Felder, and M. Meiers. 1999. Ageing of population and health care expenditure: A red herring? Health Economics 8(6):485-96. 